\title{
Fetal magnetic resonance imaging in obstetric practice
}

Fetal manyetik rezonans görüntülemenin obstetri pratiğindeki yeri

\author{
Aydın Köşüş ${ }^{1}$ Nermin Köşüş ${ }^{1}$, Betül Usluoğulları ${ }^{1}$, Müzeyyen Duran ${ }^{1}$, Nilgün Öztürk Turhan ${ }^{1}$ Mehmet Tekşam² \\ 'Department of Gynecology and Obstetric, Fatih University, Ankara, Turkey \\ ${ }^{2}$ Department of Radiology, Fatih University, Ankara, Turkey
}

\section{Abstract}

Ultrasonography (USG) is the primary imaging method for prenatal diagnosis of fetal abnormalities since its discovery. Although it is the primary method of fetal imaging, it cannot provide sufficient information about the fetus in some conditions such as maternal obesity, oligohydramnios and engagement of the fetal head. At this stage, magnetic resonance imaging (MRI) facilitates examination by providing more specific information. The need and importance of fetal MRI applications further increased by the intrauterine surgery which is currently gaining popularity. Some advantages of fetal MRI over USG are the good texture of contrast, a greater study area and visualization of the lesion and neighbourhood relations, independence of the operators. Also it is not affected by maternal obesity and severe oligohydramnios. However, MRI is inadequate in detecting fetal limb and cardiac abnormalities when compared to USG. MRI is not used routinely in pregnancy. It is used in situations where nonionizing imaging methods are inadequate or ionizing radiation is required in pregnant women. It is not recommended during the first trimester. Contrast agent (Godalinium) is not used during pregnancy. It is believed that MRI is not harmful to the fetus, although the biological risk of MRI application is not known. MRI technique is superior to USG in the detection of corpus callosum dysgenesis, third-trimester evaluation of posterior fossa malformations, bilateral renal agenesis, diaphragmatic hernia and assessment of lung maturation. Especially, it is the method of choice for evaluation of central nervous system (CNS) abnormalities. Fetal MRI has a complementary role with USG. It provides important information for prenatal diagnosis, increases diagnostic accuracy, and in turn affects the prenatal treatment, prenatal interventions and birth plan.

(J Turkish-German Gynecol Assoc 2011; 12: 39-46)

Key words: Fetal magnetic resonance imaging, fetal ultrasonography

Received: 5 August, 2010

Accepted: 19 February, 2011
Özet

Ultrasonografi (USG) keşfedilmesinden günümüze kadar fetal anomalilerin prenatal tanısında primer görüntüleme yöntemidir. Fetal görüntülemede USG primer yöntem olmasına rağmen fetus hakkında yeterli bilgi veremediği obezite, oligohidramnioz, fetal başın angajmanı gibi durumlar vardır. Bu aşamada manyetik rezonans görüntüleme (MRG) daha fazla spesifik bilgi sağlayarak bize yardımcı olmaktadır. Günümüzde giderek yaygınlaşan intrauterin cerrahi, fetal MRG uygulamalarına olan ihtiyacı ve önemini daha da arttırmaktadır. MRG'nin doku kontrastını iyi verebilmesi, inceleme alanının büyük olması ve böylece lezyon ile olan komşulukların ilişkisinin gösterilebilmesi, operatörden bağımsız oluşu, maternal obezite ve ciddi oligohidramnioz durumundan etkilenmemesi USG'ye olan üstünlüklerindendir. Ancak fetal ekstremite değerlendirilmesi ve fetal kardiyak anomali tesbitinde MRG, USG'ye göre yetersiz kalmaktadır. MRG gebelikte rutin olarak kullanılmaz. Noniyonize görüntü yöntemleri yetersiz kaldığında veya iyonoze radyasyon gerektiren durumlarda gebe kadınlarda MRG kullanılır. İlk trimesterde önerilmemektedir. Kontrast madde (Gadolinium) kullanılmaz. MRG uygulamasının biyolojik riski bilinmemekle birlikte fetusa zararlı etkisi olmadığına inanılmaktadır. Kopus kallozum disgenezisi, üçüncü trimesterde posterior fossa malformasyonlarının değerlendirilmesi, bilateral renal agenezi, diyafram hernisi ve akciğer maturasyonu saptamada MRG tekniği USG'ye üstündür. Özellikle santral sinir sistemi (SSS) anormalliklerinin değerlendirilmesinde sıklıkla kullanılan bir yöntemdir. Fetal MRG, USG'yi tamamlayıcı bir rol üstlenmekte ve prenatal tanıda önemli bilgiler sağlayarak tanı doğrulunu, prenatal tedaviyi, prenatal girişimi ve doğum planını etkileyebilmektedir.

(J Turkish-German Gynecol Assoc 2011; 12: 39-46)

Anahtar kelimeler: Fetal manyetik rezonans görüntüleme, fetal ultrasonografi

Geliş Tarihi: 05 Ağustos $2010 \quad$ Kabul Tarihi: 19 Şubat 2011

\section{Introduction}

Ultrasonography (USG) has been the primary imaging method in diagnosing fetal anomalies since its discovery (1). USG has been used since the 1950's. With the progression of technological improvements with time, imaging with real-time USG, color Doppler, power Doppler, 3 and 4 dimensional
USG has taken its place in fetal evaluation. Although USG is the primary method in fetal imaging, in situations where it cannot give sufficient information about the fetus, magnetic resonance imaging (MRI) helps us by providing more specific information (2). Nowadays the increasing intrauterine surgery has further increased the need and importance of fetal magnetic resonance imaging. In this article, the position 
of magnetic resonance imaging in obstetric practice has been presented within the frame of the literature.

\section{History}

Evaluating the fetus with MRI is not a very new method. The first definition of Fetal MRI was described by Smith and his colleagues in 1983 (3). In their early stage studies, fetal movements prevented the evaluation of fetal morphology. The suggestion was to perform this technique in cases where limited images were obtained in the late pregnancy period or in cases where the fetal movement was limited by oligohydramnios (4). Some of the researchers performed imaging by sedating the gravida with benzodiazepine or directly injecting curare into the fetus to decrease movement (5). Despite all these difficulties, MRI was accepted as an important method in evaluating fetal anomalies (6). MRI was previously used only in the evaluation of the CNS, but with the development of fast sequences completed in less than 20 seconds, the anatomy and malformations of the fetus can be imaged without using any premedication. With its ease of application and high resolution, the MRI techniques increasing popularity will obviously be helpful for obstetricians in future prenatal diagnosing.

\section{Reliability}

The biological risk of magnetic resonance imaging is unknown, but it is believed not to have a harmful effect on the fetus (7). Despite the high magnetic field in the conducted animal studies, no negative effects could be shown on fetal development (8). At the same time, a study conducted with pregnant women working in the MRI unit showed no difference from the control group in terms of pregnancy outcomes (9). Also, children undergoing fetal magnetic resonance imaging were monitored for two years and no increase in disease rates could be shown (10). Despite all these, the Food and Drug Administration (FDA) requires that the statement 'the effect on the fetus has not yet been proven' be shown on MRI devices. However, the Society of Magnetic Resonance Imaging has stated that MRI is indicated in pregnant women when other non-ionizing imaging methods are insufficient or in situations where ionizing radiation must be used (11).

There are some points that must be paid attention to when performing magnetic resonance imaging on pregnant women. It must not be used routinely in pregnancy. It is performed when cases cannot be diagnosed with ultrasonography. It is not recommended in the first trimester. Contrast material (Godolinium) must not be used. Pregnant women must be informed about the examination with a disclosure form and must give their approval before the procedure.

\section{Advantages and Disadvantages}

Ultrasound is a fetal evaluation method that has been proven to be reliable, is widely used, and is not expensive. It simultaneously provides fetal monitoring and an evaluation of the fetus' well-being. Fetal and placental blood flow evaluation is another advantage of ultrasound (12).

As well as its advantages, ultrasound also has disadvantages. First of all, it is an operator dependent method. In addition, it gives us only a small sampling area of the fetus; we cannot observe the fetus as a whole after the second trimester; the image resolution differs highly whether the examined tissue is soft tissue or bone; and as a result of the bone structures, the image quality decreases when evaluating the cranial structure. Also, the fetal position is another parameter that affects image quality. Evaluating the anatomical details in breech presentation in the prone position is very difficult. The image quality is also very low in situations like obesity, oligohydramnios and engagement of the fetal head (12-15).

In situations like these, where we cannot obtain sufficient information about the fetus, MRI does not get seriously affected It does not contain ionizing radiation. It differs from ultrasound with its high soft tissue resolution, which provides the distinction of maternal and fetal organs. The fetus can be examined three dimensionally $(12,16)$. It is a perfect method for imaging intracranial and spinal anatomy. At the same time, it is very useful in measuring organ volumes, such as the lungs. Its other advantages are not being operator dependent and obtaining more than one image. Its disadvantages can be listed as its high cost, being a method which is difficult to obtain, and the fetal-maternal-amnion fluid and extremity movements cause artifacts. This is why maternal sedation could be necessary in fetuses that move a lot. Although a distinct fetal effect has not been determined up to today, long term results are still unknown (7, 9, 10, 17-26). Therefore it is not recommended for use in pregnancies earlier than the eighteenth week (2). Also, it cannot be usd for people who suffer from claustrophobia.

\section{Technique}

The fetus must be evaluated in terms of position and fetal cardiac activity (for medicolegal reasons) before MRI. Fetal MRI is applied to the pregnant woman in the supine position. Images are obtained in sagittal, transverse and coronal planes with a T2 weighted sequence. Due to its placental transition, contrast material is not used in examinations. The nasopharynx, oropharynx, trachea and lungs are observed as hyperintense because they are filled with amniotic fluid. The aorta, pulmonary vessels and heart have hypointense signals. For this reason, we cannot differentiate the fetal heart chambers with MRI. While the thyroid gland is observed in equal intensity with its surrounding tissues in T2 weighted sequences, it can be easily distinguished from its neighboring structures in T1 weighted sequences, where it is clearly hyperintense. The stomach, small intestinal loops and colon are selected as hypointense in T2 weighted sequences because of their meconium content. The liver, spleen and kidneys have a mean signal character. The gallbladder is observed as a cystic structure next to the lower edge of the liver. The urinary bladder is a liquid filled structure that can be easily recognized in the pelvis. The scrotum and penis are frequently observed in the male fetus but the female genital organs mostly cannot be selected. 


\section{Indications}

Fetal MRI can be used in the following cases $(1,2,12,15)$ :

Situations where USG is limited:

- In the presence of maternal obesity,

- Decreased amniotic fluid cases (oligohydramios, membrane rupture),

- Third-trimester evaluation of the posterior fossa,

- The fetus position unsuitable for the evaluation with ultrasound.

Fetal assessment:

- Detailed diagnosis and analysis of anomalies that require termination of pregnancy,

- The evaluation of conditions associated with multiple anomalies,

- Intracranial and spinal malformations,

- Facial malformations such as cleft lip and palate,

- Pathology of multiple pregnancy (twin-twin transfusion, acardiac twin, etc.),

- Fetal masses,

- Thoracic lesions, evaluation of anomalies of the neck that cause compression of the airway,

- Abdominal wall defects,

- Skeletal dysplasias,

- Placenta and cord abnormalities,

- Cases where fetal surgery is planned,

- The method of birth and determining if neonatal support is needed.

The MRI technique is superior to USG in detecting corpus callosum dysgenesis, third-trimester evaluation of posterior fossa malformations, bilateral renal agenesis, diaphragmatic hernia and lung maturation. It is a frequent method used in evaluating especially central nervous system (CNS) anomalies.

\section{Fetal Central Nervous System Anomalies}

Although MRI and USG are complementary methods in evaluating the fetal central nervous system, fetal MRI provides increased contrast resolution that increases anatomical detail, and sometimes can change the diagnosis. In the evaluation of the fetal CNS with USG, there are conditions for which imaging is insufficient, such as maternal obesity, oligohydramnios and poor fetal position. Magnetic resonance imaging is less affected by these conditions (27). In 40 percent of the CNS anomalies diagnosed with USG, the diagnosis changed and in 46 percent, changes in management occurred $(14,28,29)$.

Neuroectodermal elements forming the brain paranchyme are derived from the germinal matrix that surrounds the ventricle as a thick layer. Neuronal cells migrate from the germinal matrix to the cortex between weeks 6-24, forming the temporary cerebral laminar organization. This organization is completed at the twenty-eighth week. From week 16 to week 20 the cerebral surface is observed to be smooth with the exception of the minimal Sylvian fissure. We observe an increase in the sulcus formation with maturation. Observing specific sulci with magnetic resonance imaging can determine an estimated fetal age. The observed sulcus formation is observed with a delay of 2-3 weeks later than the anatomic specimens. An extra two week delay occurs in fetuses with a central nervous system malformation. In short, the relationship between sulcus formation and gestational week is very important.

Myelin formation starts in the peripheral nervous system at week 16, in the central nervous system at week 20 and progresses with a specific sequence. Myelin formation is seen with fetal MRI in the posterior brain stem at week 20, the internal capsule posterior leg at week 33 and the subcortical area at week 35. We must look at the compliance of myelin formation with the gestational week when evaluating the fetal MRI results. The corpus callosum starts to develop at week 20 . The ventricles are observed larger with MRI compared to USG between weeks 20-24 (physiological hydrocephaly). The ventricle dimensions decrease between weeks 24-28. The ventricles seem narrower than normal between weeks 34-36 (30). Between weeks 23-36, cerebellar folds become evident and the middle cerebellar peduncle develops. This is why evaluation with MRI is best after week 24 .

\section{Neuronal migration anomalies}

Magnetic resonance imaging plays a major role in prenatal diagnosis of cortical development anomalies. MRI findings of cortical malformations are usually similar to postnatal imaging (31). Migration anomalies can be isolated or may be accompanied by other brain anomalies.

Polymicrogria is an organization disorder occurring as a result of an injury of the cortex after neuronal migration. The cortex's six-layer structure has been corrupted. This can be due to genetic and ischemic causes and infections with cytomegalovirus. The most common cause of injury is ischemia (32).

Schizencephaly is an anomaly characterized by a cleavage in the gray matter stretching from the ventricle to the cortex. The amount of cortex area determines the prognosis (33). Lissencephaly, meaning smooth brain, is having no gyrus or a very small number of gyrus-sulcus. Heterotopy is the stopping of radial migration during brain development and the abnormal localization of gray matter nerve cells. Eighty percent of lissencephaly, 73 percent of polymicrogria, 100 percent of schizencephaly and 54 percent of heterotopy were diagnosed with fetal MRI in the third trimester (34).

\section{Ventriculomegaly}

It is the most commonly observed CNS anomaly in prenatal period and is also the most common fetal MRI indication. Ventriculomegaly is diagnosed with the transatrial width being greater than $10 \mathrm{~mm}$ (35). The causes of ventriculomegaly and the accompanying anomalies can also be detected with fetal MRI. Eighty-four percent of fetuses with a ventriculomegaly diagnosis may have accompanying CNS anomalies, additive organ anomalies and chromosomal anomalies (36). In 40-50 percent of cases, associated anomalies can be shown with magnetic resonance imaging (37-39). When the ventricular width increases, the risk of additional anomalies also increases. Although fetuses with the diagnosis of mild ventriculomegaly (10-15 mm in transatrial width) are mostly healthy and normal at birth, they have a small amount of risk of intrauterine 
growth retardation (IUGR). The prognosis is much better when ventriculomegaly is isolated (40). Congenital or acquired (after infection, hemorrhage) aquaductal stenosis can be diagnosed with MRI by detecting a normal sized $4^{\text {th }}$ ventricle, expanded $3^{\text {rd }}$ ventricle and lateral ventricles (41). Ventriculomegaly can be observed with cerebral atrophy after ischemia or infection. In ventriculomegaly occurring due to ischemia or infection of the brain tissue, irregularity in ventricle walls and cortical loss can be observed (42). Thus, we can understand if ventriculomegaly is developmental, destructive or obstructive with MRI. We observe ventricular dilatation in the third and both lateral ventricles of the fetus in Figure 1.

\section{Anomalies of the corpus callosum}

Abnormalities of the corpus callosum can be identified easily with magnetic resonance imaging. The distinction of total or partial agenesis, hypoplasia of the corpus callosum can be made. CNS anomalies and non-CNS anomalies accompany corpus callosum agenesis with a rate of 85 percent and 62 percent, respectively (43). Twenty percent of the cases thought to have corpus callosum agenesis with ultrasonography were found to be normal with MRI. The diagnosis of partial agenesis is very difficult with USG. An arachnoid cyst located on the upper wall of the third ventricle can mistakenly be diagnosed as collasal agenesis. Magnetic resonance imaging technique may change the diagnosis by showing the cyst wall and the corpus callosum (44).

\section{Holoprozencephaly}

It is a congenital anomaly existing because of a cleavage defect of the prozencephalon known as the front brain. It is diagnosed by a single ventricle, fusion of the thalamus, absence of the cavum septum pellisidum and falx cerebri. The diagnosis of severe forms like semilobar and alobar holoprozencephaly can be easily recognized by observing a single ventricle and fusion of the cerebral hemispheres. However, MRI is very useful in the diagnosis of lobar form and the distinction of lobar holoprozencephaly, another cause of ventriculomegaly (45).

\section{Neural tube defects}

(Anencephaly, encephalocele, inencephaly, craniorachitism, meningocele, meningomyelocele, spina bifida occulta)
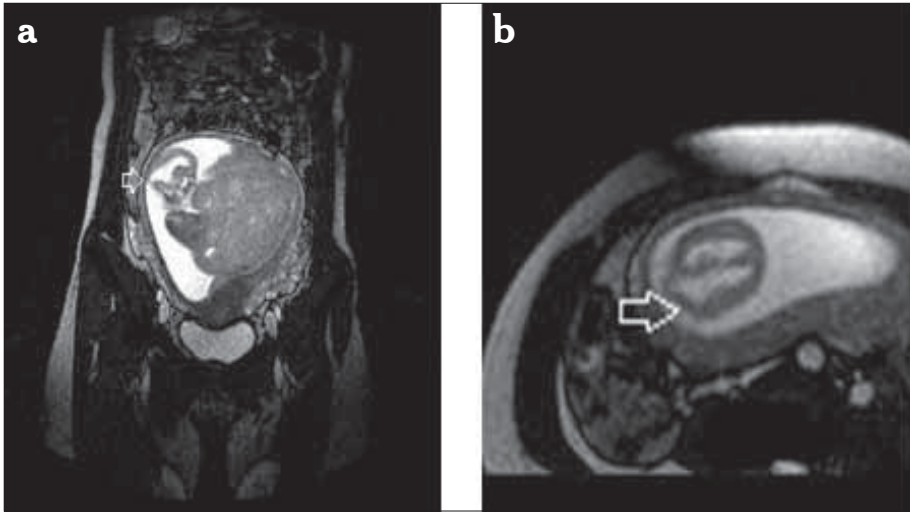

The diagnosis of neural tube defects (NTD) can be done to a large extent with sonography but USG can be insufficient in detecting mild forms of NTD or accompanying anomalies. In the study of Wang and colleagues, results showed that an abnormal vertebral body sequence was detected with USG in all of the cases with spinal malformations, but only the cases with a suspicion of meningocele and myelomeningocele could be diagnosed. He found that syringomyelia, diastematomyelia, hemivertebrae, spinal cord arachnoid cysts and tethered cord were missed. It was reported that only the diagnosis of hemivertebra could not be made with magnetic resonance imaging because of the fetal vertebra bodies being too small in size (46). An encephalocele case is seen in Figure 1 (a, b, c, d). An $11 \mathrm{~mm}$ diameter defect has been observed in the left occipital bone and a $2.5 \mathrm{~cm}$ diameter cephalocele sac was observed from this defect. Brain tissue and the herniation of the posterior of the left lateral ventricle inside the cephalocele sac are noteworthy.

\section{Posterior fossa defects}

USG does not give sufficient information about posterior fossa anomalies, especially in the third trimester. The diagnosis of these pathologies can easily be made with magnetic resonance imaging. The sisterna magna measurements larger than $10 \mathrm{~mm}$ may suggest Dandy-Walker malformation, Dandy-Walker variant (partial wermian agenesis), mega sisterna magna, cerebellar hypoplasia or arachnoid cyst $(47,48)$. In the Dandy-Walker malformation there are vermis agenesis, dilatation of the fourth ventricle and elongating of the posterior fossa below the tentorium. Sixty-eight percent of supratentorial malformations are accompanied by Dandy-Walker malformation. MRI also provides the differentiation of posterior fossa arachnoid cysts from vermian development anomalies (44).

\section{Tuberous sclerosis}

It is an autosomal dominant disorder proceeding with mental retardation and seizures that can also have involvement of the brain, heart, skin, kidney and other organs. MRI is highly effective in demonstrating cardiac rhabdomyomas and subependymal tubers before week 21. The differentiation of tubers from hamartomas and subcortical heterotopic brain tissue can be made (49).
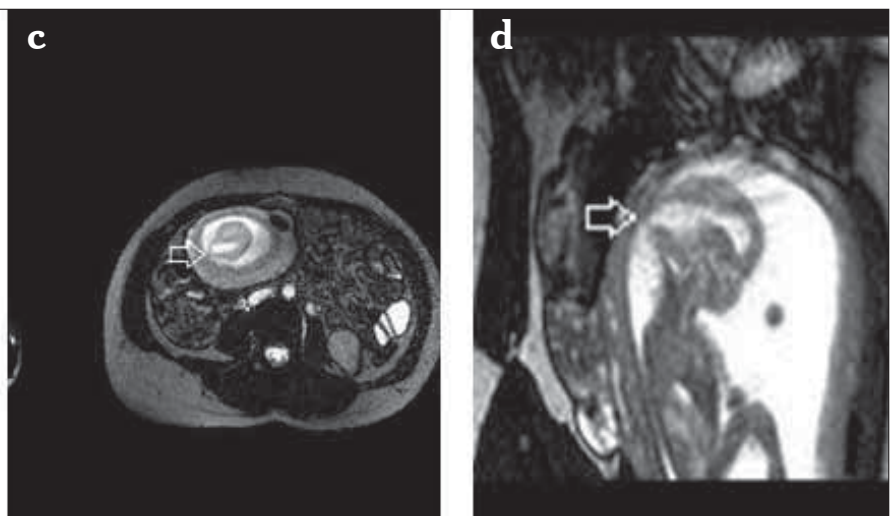

Figure 1. A case with ventriculomegaly and encephalocele 


\section{Sacrococcygeal teratoma}

It is a cystic or solid tumor located at the coccyx that is classified according to its extra or intrapelvic component. Type 1 is an external presacral component, Type 2 is a small presacral component accompanying the external component, Type 3 is a small extrapelvic component with an intrapelvic and intraabdominal elongation, Type 4 frequently elongates towards the whole pelvis and abdomen. It is often accompanied by polyhydramnios. Hydrops may be seen due to compression of the fetal aorta and inferior vena cava and increased fetal cardiac output. Vascularity increases with an increase in the solid component. Magnetic resonance imaging shows the tumor's intrapelvic and intraspinal elongation. It gives a better discrimination between sacral myelomeningocele and cystic sacrococcygeal tumors (50). In Figure 2 (a, b), a 14x11x11 cm sized sacrococcygeal teratoma filling the whole fetal pelvis showing exophytic extensions to the pelvic and anal regions is seen.

\section{Intracranial bleeding and destructive lesions}

The frequency of intrauterine ischemia is unknown, but a study reported that 14 percent of perinatal mortalities occurred due to ischemic changes. Ischemic injury may result in very different appearances, such as ventriculomegaly, microcephaly, hydrocephalus, porencephaly, encephalomalacia, capsular ischemia and cerebral atrophy. Morphology depends on the affected area, and the time between the damage and imaging. Magnetic resonance imaging is superior to USG in diagnosing these lesions $(23,44,51)$.

\section{Fetal Neck Anomalies}

Although fetal neck masses are not common, they are important because they can cause airway obstruction at birth. Among the neck masses cystic hygroma, goiter and teratomas are the most frequent. Teratomas are midline lesions that can be

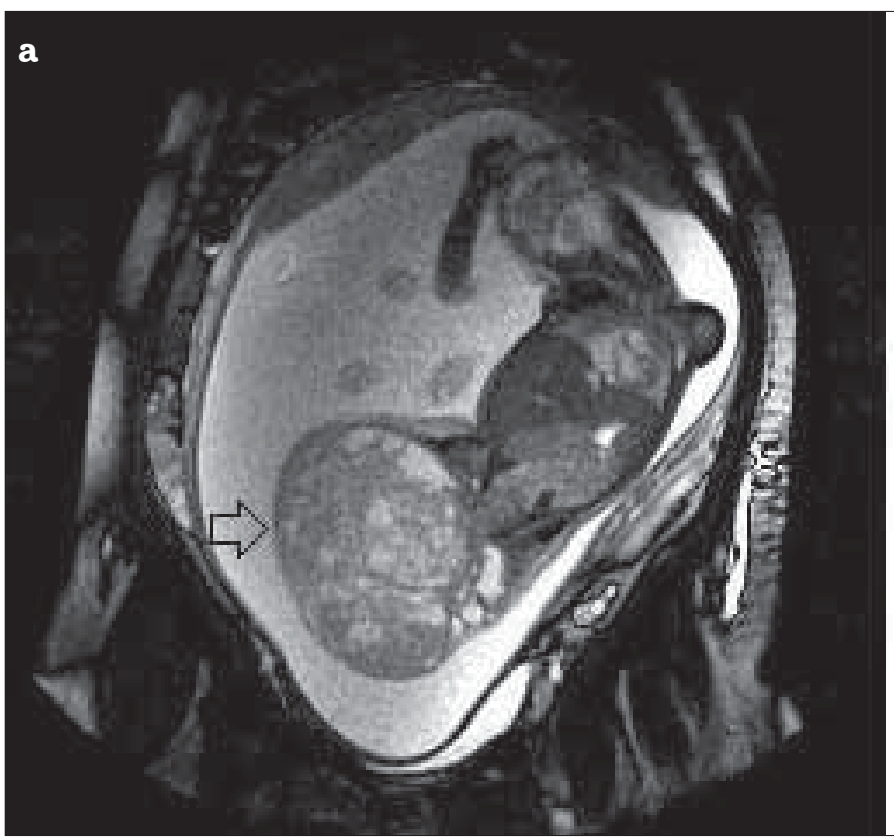

solid or cystic. Cystic hygroma may be accompanied by Down syndrome, Trisomy 18, Turner syndrome, and hydrops fetalis. Magnetic resonance imaging has an important role in characterizing the lesion and describing the relationship between large vascular structures and the airway (52).

Obstruction of the trachea and larynx causes the lungs to overinflate, a flattening of the diaphragm, and a decrease in the venous return to the heart, resulting in fetal hydrops and ascites. Bilateral hyperechoic enlarged lungs, flattening or eversion of the diaphragm, fluid leveling in the airways under the obstruction, fetal hydrops and ascites can be shown with ultrasonography. All these findings can also be described with MRI (53).

\section{Fetal Thoracic Anomalies}

Management of fetal abnormalities in the fetal thorax is very important in terms of prognosis. Especially the localization of a thoracic mass and its relationship with other organs provides us with important information. Sometimes, bronchial atresia, tracheal atresia, or pulmonary atresia can be diagnosed as cystic adenoid malformation with USG. Fetal MRI is very useful in these cases. In a study conducted by Hubberd and colleagues, the USG diagnosis of fetal thoracic anomalies changed in 50 percent of cases after performing a MRI (54).

Fetal lung maturation is very important in terms of fetal prognosis and can be detected with signal changes in T1-T2-weighted sequences with fetal MRI (55). Congenital cystic adenoid malformation, bronchopulmonary sequestration, fetal hydrothorax and congenital diaphragmatic hernia are commonly seen thoracic masses.

\section{Congenital cystic adenomatoid malformation}

They are multicystic masses associated with the normal bronchial system of the lung which are formed by bronchioles showing abnormal proliferation. Its feeding artery is from the

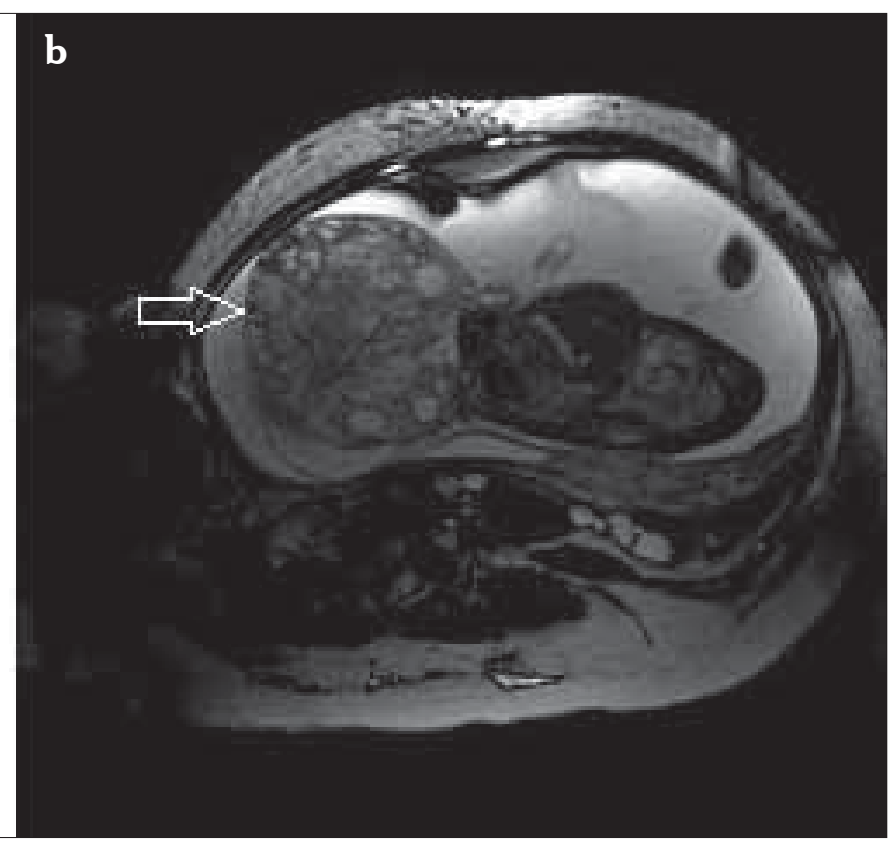

Figure 2. A case with sacrococcygeal teratoma 
aorta and its venous drainage is to the pulmonary vein. It can originate from one lobe and segment or multiple lobes. Type 1 is macrocystic, Type 2 is a small macrocystic form. Type 3 includes solid and microcystic areas and has a poor prognosis. Typing can be done with magnetic resonance imaging as well as showing a better lung tissue compression when compared with USG (44).

\section{Bronchopulmonary sequestration}

It is a structure occurring from a nonfunctional lung tissue that is not related to the tracheobronchial system. It can be intralobar or extralobar. The extralobar one has its own pleura and feeding artery from the systemic circulation. Bronchopulmonary sequestration (BPS) has a relatively good prognosis. These vascular structures can be observed better with Doppler USG. Bronchopulmonary sequestration can be confused with adrenal tumors when it is located at the upper abdomen and MRI could be used for their differentiation (56).

\section{Congenital diaphragmatic hernia}

It mostly (90 percent) originates from the left posteriolateral region of the diaphragm. Only 10 percent originate from the right diaphragm. In two percent of the cases it can be bilateral. Fetal survival varies between 40 percent and 90 percent (57). The degree of pulmonary hypoplasia associated with the congenital diaphragmatic hernia, liver herniation and size of hernia sac is very important in determining the prognosis (58). The organs herniated into the thoracic cavity can easily be selected with magnetic resonance imaging. More frequently, the stomach, small intestine and colon, also liver, gallbladder and spleen are the organs that can be herniated. Comments can be made in terms of prognosis by determining the existing fetal lung volume.

\section{Fetal Abdominal Organ Anomalies}

The liver tissue can be evaluated very well with MRI. During fetal development the liver shows signal changes. By looking at the measurement changes of the T2-weighted series of the fetal liver after maternal oxygenation, evaluation of abnormalities such as placental insufficiency and IUGR can be carried out (59). Hemangioendothelioma, hepatoblastoma, and hamartomas are rare liver masses seen in the fetus. These lesions have specific magnetic resonance images.

Meconium can be seen in the rectum as early as the fourteenth week with fetal MRI. If mecomium is not visible in the middledistal intestines we could suspect atresia or perforation. Cystic abdominal masses can be differentiated from intestinal atresia with fetal MRI,and it can also show the location of the intestinal atresia (60). MRI can be helpful in verifying anterior abdominal wall defects.

As renal anomalies are frequently associated with oligohydramnios, detection of anomalies with USG is often difficult. In complex urinary system anomalies like primary megaureter, horse shoe kidney, renal agenesis, bladder extrophy and cloacal anomaly, MRI is very helpful in the diagnosis of imperforate hymen and hydrocolpos.

\section{Skeletal Anomalies}

In general, an idea about the development of the skeleton and the size of the thorax can be obtained with MRI. It can also provide information about the details of the development of the pineal gland (61).

\section{Monozygotic Twin Pregnancy Complications}

Specific complications such as twin to twin transfusion syndrome, acardiac twins, conjoined twins and embolization syndrome create an indication for fetal surgery intervention in monochorionic twins (62). Some of these complications are associated with the neurological damage caused by thrombotic ischemia (63). Parenchymal destruction can be detected with MRI (23). The best indicator of ischemic injury is the cavitary lesions that can be visualized on MRI two weeks after ischemic injury. In the future, diffusion MRI technique may allow earlier identification of ischemic damaging.

\section{Placental Invasion}

Placental invasion anomalies are frequently associated with uterine surgery, uterine infections and placenta previa. Magnetic resonance imaging is a complementary method for ultrasound in patients who have a placental invasion risk. The USG findings of placental invasion are subplacental hypoechoic zone loss, accompanying placenta previa in most cases, detection of a large number of large intervillous ponds inside which blood flow can be observed, with large vessels expanding into the myometrium.

The magnetic resonance imaging findings in T2-weighted sequences can be seen as myometrial loss, placental tissue signal exceeding the uterine border, and loss of the fat tissue between the uterine and pelvic organs. Lax and colleagues described placental invasion with MRI with the findings of heterogeneous signal intensity inside the placenta, hypointense intraplacental band in T2 weighted sequences, and swelling of the lower uterine (64). Using godolinium in magnetic resonance imaging can help in providing discrimination of the placenta and myometrium, but because of its placental transmission the profit-loss rate must be taken into consideration. Diffusion weighted MRI based on the specific diffusion of water molecules in the tissue provides a characteristic image for the tissue. The normal endometrium has high signal intensity because of its dense cells and abundant cytoplasm. On the basis of this hypothesis, the investigation of the diagnosis of placental invasion with diffusion MRI can become easier (65). In conditions such as posterior located placenta and a previous caesarean section where imaging especially with MRI is difficult, evaluating the placenta with USG must be considered.

\section{Volumetric Measurements}

Whole fetus volume or single organ volume measurements can be made easily and accurately with fetal MRI (66). Lung volume is important in determining the degree of pulmonary hypoplasia and liver volume is important in diagnosing IUGR. 


\section{Conclusion}

Ultrasonography still remains the first choice in prenatal diagnosis. However, with the development of prenatal treatment methods, the importance of prenatal diagnosis is gradually increasing. The superiorities of magnetic resonance imaging to USG are; giving good tissue contrast, the large study area thus demonstrating the lesion and its relationship between the neighboring structures, being operator independent, not being affected by maternal obesity and severe oligohydromnios. However, MRI is insufficient in the evaluation of fetal limbs and the detection of fetal cardiac anomalies according to USG. Fetal MRI has a complementary role for USG and can affect diagnosis accuracy, prenatal treatment, the prenatal approach and birth planning by providing important information in prenatal diagnosis.

\section{Conflict of interest}

None declared.

\section{References}

1. Pugash D, Brugger PC, Bettelheim D, Prayer D. Prenatal ultrasound and fetal MRI: The comparative value of each modality in prenatal diagnosis. Eur J Radiol 2008; 68: 214-26. [CrossRef]

2. Kline-Fath B, Bitters C. Prenatal Imaging. Newborn Infant Nurs Rev 2007; 7: 197-204. [CrossRef]

3. Smith FW, Adam AH, Phillips WDP. NMR imaging in pregnancy. Lancet 1983; 1: 61-2.

4. McCarthy S. Magnetic resonance imaging in obstetrics and gynecology. Magn Reson Imaging 1986; 4: 59-66. [CrossRef]

5. Levine, Deborah MD. Magnetic resonance imaging in prenatal diagnosis. Curr Opin Pediatr 2001; 13: 572-8. [CrossRef]

6. Reiss I, Gortner L, Moller J, Gehl HB, Baschat AA, Gembruch U. Gembruch U. Fetal intracerebral hemorrhage in the second trimester: diagnosis by sonography and magnetic resonance imaging. Ultrasound in obstet gynecol 1996; 7: 49-51. [CrossRef]

7. Chew S, Ahmadi A, Goh PS, Foong LC. The effects of 1.5T magnetic resonance imaging on early murine in-vitro embryo development. J Magn Reson Imaging. 2001; 13: 417-20. [CrossRef]

8. O'Connor M. Intrauterine effects in animals exposed to radiofrequency and microwave fields. Teratology 1999; 59: 287-91. [CrossRef]

9. Kanal E, Gillen J, Evans JA, Savitz DA, Shellock FG. Survey of reproductive health among female MR workers. Radiology 1993; 187: 395-9.

10. Baker P, Johnson I, Harvey P, Gowland PA, Mansfield P et al. A three-year follow-up of children imaged in utero with echo-planar magnetic resonance. Am J Obstet Gynecol 1994; 170: 32-9.

11. Shellock FG, Kanal E. Policies, guidelines, and recommendations for MR imaging safety and patient management. SMRI Safety Committee. J Magn Reson Imaging 1991; 1: 97-101. [CrossRef]

12. Levine D. Ultrasound versus magnetic resonance imaging in fetal evaluation. Top Magn Reson Imaging 2001; 12: 25-38. [CrossRef]

13. Hubbard AM. Magnetic resonance imaging of fetal thoracic abnormalities. Top Magn Reson Imaging 2001; 12: 18-24. [CrossRef]

14. Levine D, Barnes PD, Madsen JR, Li W, Edelman RR. Fetal central nervous system anomalies: MR imaging augments sonographic diagnosis. Radiology 1997; 204: 635-42.

15. Hubbard AM, Simon EM. Fetal imaging. Magn Reson Imaging Clin $\mathrm{N}$ Am 2002; 10: 389-408. [CrossRef]

16. Stazzone MM, Hubbard AM, Bilaniuk LT, Harty MP, Meyer JS, Zimmerman RA et al. Ultrafast MR imaging of the normal posterior fossa in fetuses. AJR Am J Roentgenol 2000; 175: 835-9.
17. Wolff S, Crooks LE, Brown P, Howard R, Painter RB. Tests for DNA and chromosomal damage induced by nuclear magnetic resonance imaging. Radiology 1980; 136: 707-10.

18. Reid A, Smith FW, Hutchison JM. Nuclear magnetic resonance imaging and its safety implications: Follow-up of 181 patients. Br J Radiol 1982; 55: 784-6. [CrossRef]

19. Schwartz JL, Crooks LE. NMR imaging produces no observable mutations or cytotoxicity in mammalian cells. AJR Am J Roentgenol 1982; 139: 583-5.

20. Kanal E, Shellock FG, Talagala L. Safety considerations in MR imaging. Radiology 1990; 176: 593-606.

21. Shellock FG, Kanal E. Guidelines and recommendations for MR imaging safety and patient management. III. Questionnaire for screening patients before MR procedures. The SMRI Safety Committee. J Magn Reson Imaging 1994; 4: 749-51. [CrossRef]

22. Athey TW. FDA regulation of the safety of MR devices: Past, present, and future. Magn Reson Imaging Clin N Am 1998; 6: 791-5.

23. Myers C, Duncan KR, Gowland PA, Johnson IR, Baker PN. Failure to detect intrauterine growth restriction following in utero exposure to MRI. Br J Radiol 1998; 71: 549-51.

24. Levine D, Zuo C, Faro CB, Chen Q. Potential heating effect in the gravid uterus during MR HASTE imaging. J Magn Reson Imaging 2001; 13: 856-61. [CrossRef]

25. Okuda Y, Sagami F, Tirone P, Morisetti A, Bussi S, Masters RE. [Reproductive and developmental toxicity study of gadobenate dimeglumine formulation (E7155) (3)-Study of embryo-fetal toxicity in rabbits by intravenous administration]. J Toxicol Sci 1999; 24: 79-87.

26. Novak Z, Thurmond AS, Ross PL, Jones MK, Thornburg KL, Katzberg RW et al. Gadolinium-DTPA transplacental transfer and distribution in fetal tissue in rabbits. Invest Radiol 1993; 28: 828-30. [CrossRef]

27. D. Levine. MR imaging of fetal central nervous system abnormalities, Brain Cognition 2002; 50: 432-48. [CrossRef]

28. Simon E, Goldstein R, Coakley F, Filly RA, Broderick KC, Musci $\mathrm{TJ}$ et al. Fast MR imaging of fetal CNS anomalies in utero. Am J Neuroradiol 2000; 21: 1688-98.

29. Levine D, Barnes PD, Madsen JR, Abbott J, Mehta T, Edelman RR. Central nervous system abnormalities assessed with prenatal magnetic resonance imaging. Obstet Gynecol 1999; 94: 1011-9. [CrossRef]

30. Lan LM, Yamashita Y, Tang Y, Sugahara T, Takahashi M, Ohba T et al. Normal Fetal Brain Development: MR Imaging with a Half-Fourier Rapid Acquisition with Relaxation Enhancement Sequence. Radiology 2000; 215: 205-10.

31. Brisse H, Fallet C, Sebag G, Nessmann C,Blot P, Hassan M. Supratentorial parenchyma in the developing fetal brain: In vitro MR study with histologic comparison. Am J Neuroradiol 1997; 18: 1491-7.

32. Barkovich A, Rowley H, Bollen A. Correlation of prenatal events with the development of polymicrogyria. Am J Neuroradiol 1995; 16: 822-7.

33. Denis D, Maugey-Laulom B, Carles D, Pedespan JM, Brun M, Chateil JF. Prenatal diagnosis of schizencephaly by fetal magnetic resonance imaging. Fetal Diagn Ther 2001; 16: 354-9. [CrossRef]

34. Sonigo P, Rypens F, Carteret M, Delezoide AL, Brunelle FO et al. MR imaging of fetal cerebral anomalies. Pediatri Radiol 1998; 28: 212-22. [CrossRef]

35. Cardoza JD, Goldstein RB, Filly RA. Exclusion of fetal ventriculomegaly with a single measurement: the width of the lateral ventricular atrium. Radiology 1988; 169: 711-4.

36. Chervenak FA, Duncan C, Ment LR, Hobbins JC, McClure M, Scott D et al. Outcome of fetal ventriculomegaly. Lancet 1984; 2: 179-81. [CrossRef]

37. Wagenvoort AM, Bekker MN, Go AT, Vandenbussche FPHA, van Buchem MA, Valk J, van Vugt JMG. Ultrafast scan magnetic resonance in prenatal diagnosis. Fetal Diagn Ther 2000;15(6):364372. [CrossRef]

38. de Laveaucoupet J, Audibert F, Guis F, Rambaud C, Suarez B, Boithias-Guerot $\mathrm{C}$ et al. Fetal magnetic resonance imaging (MRI) of ischemic brain injury. Prenat Diagn 2001;21: 729-36. [CrossRef] 
39. Coakley FV, Hricak H, Filly RA, Barkovich AJ, Harrison MR. Complex fetal disorders: effect of MR imaging on management-preliminary clinical experience. Radiology 1999; 213: 691-6.

40. Vintzileos AM, Campbell WA, Weinbaum PJ, Nochimson DJ. Perinatal Management and Outcome of Fetal Ventriculomegaly Obstet Gynecol 1987; 69: 5-11.

41. Nyberg DA, Mack LA, Hirsch J, Pagon RO, Shepard TH. Fetal hydrocephalus: Sonographic detection and clinical significance of associated anomalies. Radiology 1987; 163: 187-91.

42. Toma P, Lucigrai G, Ravegnani M, Carıatı M, Magnano G, Lituanıa M. Hydrocephalus and porencephaly: Prenatal diagnosis by ultrasonography and MR imaging. Comput Assist Tomograph 1990; 14: 843-5.

43. Gupta JK, Lilford RJ. Assessment and managemen tof fetal agenesis of the corpus callosum. Prenat Diagn 1995; 15: 301-12 .

44. Hubbard AM. Ultrafast Fetal MRI and Prenatal Diagnosis. Seminars in Pediatric Surgery 2003; 12: 143-53. [CrossRef]

45. TomaP,CostaA,Magnano G, Cariati M, LituaniaM. Holoprosencephaly: Prenatal diagnosis by sonography and magnetic resonance imaging. Prenat Diagn 1990; 10: 429-36. [CrossRef]

46. Wang GB, Shan RQ, Ma YX, Shi H, Chen LG, Liu W et al. Fetal central nervous system anomalies: comparison of magnetic resonance imaging and ultrasonography for diagnosis. Chin Med J (Engl) 2006; 119: $1272-7$

47. Kubik-Huch RA, Huisman TA, Wisser J, Gottstein-Aalame N, Debatin JF, Seifert B et al. Ultrafast MR imaging of the fetus. AJR 2000; 174: 1599-606.

48. Dihn DH, Wright RM, Hanigan WC. The use of magnetic resonance imaging for the diagnosis of fetal intracranial anomalies. Child's Nerv Syst1990; 6: 212-5. [CrossRef]

49. Levine D, Barnes P, Korf B, Edelman R. Tuberous sclerosis in the fetus: Second-trimester diagnosis of subependymal tubers with ultrafast MR imaging. Am J Roentgenol 2000; 175: 1067-9.

50. Avni FE, Guibaud L, Robert Y, Segers V, Ziereisen F, Delaet MH et al. MR imaging of fetal sacrococcygeal teratoma: Diagnosis and assessment. Am J Roentgenol 2002; 78: 179-83.

51. Low JA, Simpson LL, Ramsey DA: The clinical diagnosis of asphyxia responsible for brain damage in the human fetus. Am J Obstet Gynecol 1992; 167: 11-5.

52. Hubbard AM, Crombleholme T, Adzick NS. Prenatal MRI evaluation of giant neck masses in preparation for fetal exit procedure. Am J Perinatol 1998; 15: 253-7. [CrossRef]

53. Coakley FV, Lopoo JB, Lu Y, Hricak H, Albanese CT, Harri- son MR et al. Volumetric assessment of normal and hypoplastic fetal lungs by prenatal single-shot RARE MR imaging. Radiology 2000; 216: 107-11.

54. Hubbard AM, Adzick NS, Crombleholme TM, Coleman BG, Howell LJ, Haselgrove JC et al. Congenital chest lesions: Diagnosis and characterization with prenatal MR imaging. Radiology 1999; 212: 43-8.
55. Duncan K, Gowland P, Freeman A, Issa B, Moore R, Baker PN et al. The changes in magnetic resonance properties of the fetal lungs: A first result and a potential tool for the non-invasive in utero demonstration of fetal lung maturation. Br J Obstet Gynecol 1999; 106: 122-5. [CrossRef]

56. Pumberger W, Moroder W, Weisbauer P. Intraabdominal extralobar pulmonary sequestration exhibiting cystic adenomatoid malformation: Prenatal diagnosis and characterization of a left suprarenal mass in the newborn. Abdom Imaging 2001; 26: 28-31. [CrossRef]

57. Harrison M, Adzick N, Estes J, Howell LJ. A prospective study of the outcome of fetuses with diaphragmatic hernia. J Am Med Assoc 1994; 271: 382-4. [CrossRef]

58. Walsh DS, Hubbard AM, Olutoye OO, Howell LJ, Crombleholme TM, Flake AW et al. Assessment of feta lung volumes and liver herniation with magnetic resonance imaging in congenital diaphragmatic hernia. Am J Obstet Gynecol 2000; 183: 1067-9. [CrossRef]

59. Semple SI, Wallis F, Haggarty P, Abramovich D, Ross JA, Redpath TW et al. The measurement of fetal liver T2* in utero before and after maternal oxygen breathing: Progress towards a non-invasive measurement of fetal oxygenation and placental function. Magn Reson Imaging 2001; 19: 921-8. [CrossRef]

60. Benachi A, Sonigo P, Jouannic JM, Simon I, Révillon Y, Brunelle F et al. Determination of anatomical location of an antenatal intestinal occlusion by magnetic resonance imaging. Ultrasound Obstet Gynecol 2001; 18: 163-5. [CrossRef]

61. Malinger G, Brugger PC, Prayer D. Fetal MRI of the femurpreliminary results. Ultrasound Obstet Gynecol 2006; 27: 593.

62. Bajoria R, Wee LY, Anwar S, Ward S. Outcome of twin pregnancies complicated by single intrauterine death in relation to vascular anatomy of the monochorionic placenta. Hum Reprod 1999; 14: 2124-30. [CrossRef]

63. Haverkamp F, Lex C, Hanisch C, Fahnenstich H, Zerres K. Neurodevelopmental risks in twin-to-twin transfusion syndrome: preliminary findings. Eur J Paediatr Neurol 2001; 5: 21-7. [CrossRef]

64. Lax A, Prince MR, Mennitt KW, Schwebach JR, Budorick NE. The value of specific MRI features in the evaluation of suspected placental invasion. Magn Reson Imaging 2007; 25: 87-93. [CrossRef]

65. Morita S, Ueno E, Fujimura M, Muraoka M, Takagi K, Fujibayashi M. Feasibility of Diffusion-Weighted MRI for Defining Placental Invasion. J Magn Reson Imaging 2009; 30: 666-71. [CrossRef]

66. Baker PN, Johnson IR, Gowland PA, Hykin J, Adams V, Mansfield P et al. Measurement of fetal liver, brain, and placental volumes with echo-planar magnetic resonance imaging. Br J Obstet Gynaecol 1995; 102: 35-9. [CrossRef]. 